TAPROBANICA, ISSN 1800-427X. April, 2013. Vol. 05, No. 01: pp. 36-43, 1 pl.

(C) Taprobanica Private Limited, 146, Kendalanda, Homagama, Sri Lanka.

www.taprobanica.org

\title{
CURRENT STATUS OF Cnemaspis littoralis (JERDON, 1853) (SAURIA: GEKKONIDAE) WITH DESIGNATION OF A NEOTYPE
}

\author{
Vivek Philip Cyriac $^{1}$ and P. K. Umesh ${ }^{2}$
}

\footnotetext{
${ }^{1}$ Centre for Wildlife Studies, Kerala Veterinary and Animal Sciences University, Pookode, Wayanad, India; Email: vivek.geckobia@gmail.com

${ }^{2}$ Pavukandy House, Moolad post, Narayamkulam, Kozhikode 673614, India
}

\begin{abstract}
The gecko Cnemaspis littoralis was described by Jerdon in 1853 from a single specimen found in a warehouse on the sea coast of Malabar. A search of the reptile collection of the ZSI failed to uncover any trace of the type specimen of this species; similar searches of the reptile collections of BMNH also proved abortive. Manamendra-Arachchi et al. (2007) also highlighted the need of designating a neotype as the type had been lost. Therefore we ascertain that Jerdon's type of Cnemaspis littoralis is lost. Hence here we redescribe this species based on specimens collected from the coasts of Kozhikode district of Kerala and designate a neotype for the taxon. Cnemaspis littoralis is distinguished from all other species of Indian Cnemaspis by its overall slender form; few scattered, small, spine like tubercles on flanks; dorsal scales homogeneous; enlarged hexagonal subcaudals and large number of femoral pores (15-18) in males. We also provide observations on the natural history, reproduction and interactions of this species with invertebrates.
\end{abstract}

Keywords: holotype, redescription, taxonomy, distribution, Malabar, ecology, India.

\section{Introduction}

The genus Cnemaspis Strauch, 1887 is one among the most speciose gekkotan genera in the family Gekkonidae, represented by more than 100 species from South \& South-east Asia and Africa (http://www.reptile-database.org). Within the last few years, the Southeast Asian and Sri Lankan species of Cnemaspis, have undergone extensive taxonomic revisions resulting in numerous new species (http://www.reptile-database.org). In India, the genus was given sufficient attention during the colonial period (Beddome, 1870a,b; Gray , 1846; Jerdon, 1853; Theobald, 1876; Annandale, 1915). However, in recent years, there have been very few studies and the diversity within this genus in India is largely underestimated (Bauer, 2002; Das \& Bauer, 2000; Mukherjee et al., 2005). The most comprehensive review of this genus in India is by Manamendra-Arachchi et al. (2007). They 
provided detailed descriptions of most of the peninsular Indian species based on the examination of museum specimens, but could not find any name bearing types for two species; C. mysoriensis (Jerdon, 1853), described from Bangalore and $C$. littoralis (Jerdon, 1853), described from the coasts of Malabar. Explorations in Bangalore have led to the redescription of $C$. mysoriensis and a neotype has been designated for the species (Giri et al., 2009). Recent field work in Kerala has revealed the existence of $C$. littoralis from the Kozhikode district, which was earlier a part of the Malabar region. We herein designate a neotype and redescribe the species.

Cnemaspis littoralis was originally described as Gymnodactylus littoralis by Jerdon in 1853, based on a single specimen found in a warehouse on the sea coast of Malabar. Subsequent reviews of this lizard by Günther (1864) and Theobald (1876) provided merely a short description with the distribution as the sea coast of Malabar. Günther (1875), considered G. planipes described by Beddome in 1871 from Nellicootah, below the Nilgiris, to be a synonym of $G$. littoralis. Boulenger (1885) supported Günther's view based on examining the types of G. planipes collected by Beddome and gave the distribution of $G$. littoralis as Nellicottah and Nilambar. Smith (1935) mentioned the distribution of Cnemaspis littoralis as Nilambur and Nellakota, on the western side of the Nilgiris. He also suggested that Jerdon's type of Gymnodactylus littoralis, from the sea coast of Malabar, was probably an imported individual. Murthy's (1990) description of this species was meagre and mentioned its distribution as Nilambur, Kerala and Nellakota, Nilgiris, Tamil Nadu. The same was followed by Tikader \& Sharma (1992) but they added Malabar in their distribution of this species. Inger et al. (1984a,b) reported this species from Ponmudi Hills of Trivandrum District, Kerala. They reported 3 individuals, two of which were found in evergreen forests at an altitude of 310-360 $\mathrm{m}$ a.s.l. and the other was from moist deciduous forest at $260 \mathrm{~m}$ a.s.l. The most recent report of $C$. littoralis is by Srinivasan et al. (1998) who reported this species from three sacred grooves viz. Iringole in Ernakulam district, Mookuthala in Malapuram district and Sangukulangara in Thrissur districts of Kerala state. Apart from these, there is no other record of this species and the lack of a name-bearing type leaves the identity of this gecko in doubt.

\section{Materials and Methods}

Field sampling was carried out in different parts of Kerala state; some specimens were collected, photographed in life, euthanized and fixed in $10 \%$ formalin. The following measurements were taken to the nearest 0.1 $\mathrm{mm}$ : SVL, snout to vent length (distance from tip of snout to anterior margin of vent); $A G$, distance from axilla to groin; TW, trunk width (maximum width of the body); ED, eye diameter (horizontal diameter of the orbit); EN, distance between anterior point of the orbit to the posterior part of the nostril; ES, snout length (distance from anterior margin of the orbit to the tip of the snout); ET, distance from posterior margin of the orbit to the anterior margin of the ear opening; IN, internarial distance (least distance between the inner margins of the nostrils); TD, tympanum diameter (horizontal distance from the anterior to posterior margin of the ear opening); HL, head length (distance from tip of snout to posterior edge of mandible; HW, head width (maximum width of the head); HD, head depth (maximum depth of the head); IO, interorbital distance (shortest distance between the superciliary scale rows); UAL, upper arm length (distance from axilla to elbow); LAL, lower arm length (distance from elbow to wrist); PAL, palm length (distance from wrist to the tip of the longest finger); FL, finger length (distance from the tip of the finger to the nearest fork); FEL, femur length (distance from groin to the knee); TBL, tibia length (distance from knee to heel); TOL, toe length (distance from tip of toe to the nearest fork); TL, tail length (distance between posterior margin of vent to the tip of the tail); TBW, tail base width.

The pholidosis recorded included number of supralabials and infralabials up to the angle of the jaw on the left and right side; number of mid-ventral scale rows; subdigital lamellae on the IV manus; subdigital lamellae on IV pes and number of femoral pores on the left and right femur. All the specimens were deposited at the museum of the Zoological Survey of India, Western Ghats Regional Center (ZSI WGRC). Opportunistic observations were also made on the natural history of these lizards in Narayamkulam, Kozhizode district, Kerala. 


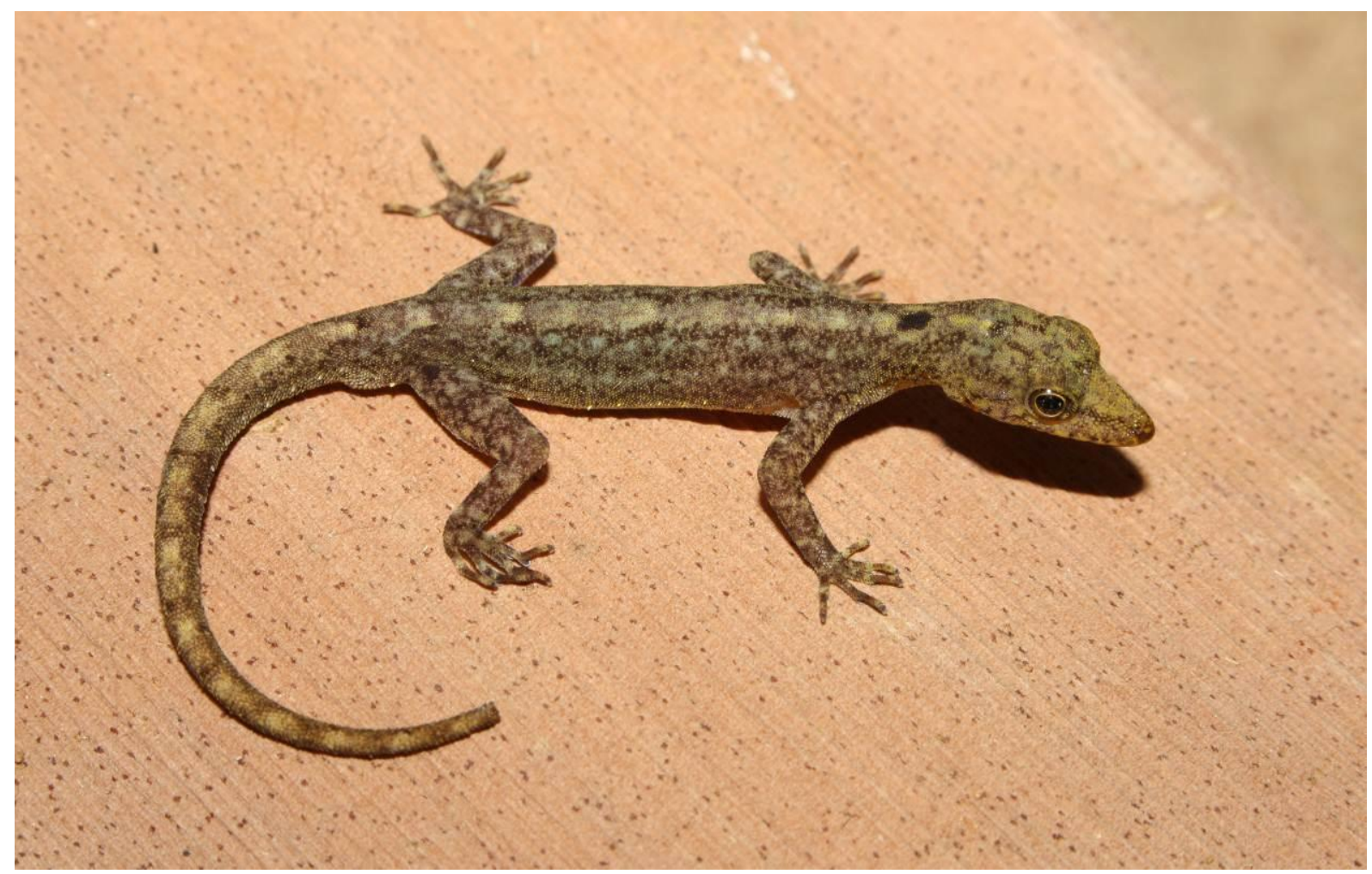

Figure 1: Cnemaspis littoralis: neotype ZSI/WGRC/IR/V/2377, male (31.5 mm SVL) in life

\section{Cnemaspis littoralis (Jerdon 1853)}

(Figure 2A-F in the plate, Table 1)

Neotype: ZSI/WGRC/IR/V/2377: adult male (31.5 mm SVL); Chaliyam coast, $13 \mathrm{~km}$ from Calicut City, Kozhikode District, Kerala, India (11.16095 N, 75.80838 E); Umesh P. K.; 6 February 2012.

Diagnosis: Cnemaspis littoralis differs from all other Indian Cnemaspis by the following characters. Maximum SVL, $31.6 \mathrm{~mm}$; overall slender form; few scattered spine like tubercles on flanks; dorsal scales of body and tail homogenous; 15-18 femoral pores in males; subcaudals in median row, enlarged and hexagonal; supralabials to angle of jaw, 9-10; infralabials, 7-9; basal 4-6 lamellae on digits enlarged; a distinct black spot on the nape.

Description of Neotype: An adult male of $31.5 \mathrm{~mm}$ SVL. Head relatively long (HL $28.9 \%$ of SVL), moderately broad (HW 58.2\% of HL), strongly depressed (HD 38.5\% of HL), distinct from neck. Snout shorter than head length (ES $42.8 \%$ of HL); scales on the snout smooth, larger than those on the forehead and interorbital region. Eye relatively small (ED $43.6 \%$ of ES), pupils round. Interorbitals moderately broad (IO 54.7\% of HW). Scales on interorbitals and supercilium smooth. Ear opening deep, small (TD 5.5\% of HL), longer than broad. Rostrals wider than long, partially divided by a median groove. Two supranasals separated from each other by an internasal. Nostrils circular; surrounded by two postnasals, supranasal and rostral. Mental subtriangular, broader than rostral; two pairs of postmentals, inner pair larger and separated by a small intermediate chin shield; inner postmentals bounded by mental, first infralabial, outer postmentals and two chin shields; outer postmentals bounded by inner postmental, first infralabial, second infralabial and three chin shields. Supralabials to angle of jaws 9; infralabials to angle of jaw 8. Scales on the ventral surface of head, smooth, granular.

Body slender (TW $19.4 \%$ of SVL), elongate (AG $45.4 \%$ of SVL). Dorsal scales homogenous, granular; few very small spine like tubercles on the dorsolateral side of the body; flanks with few small, scattered, subconical, spine like tubercles. Ventral scales larger than dorsal scales, smooth, subimbricate. Mid-body scale rows across belly 26 . Femoral pores 17; four rows of enlarged, juxtaposed 
scales above the femoral pores; no precloacal pores; precloacal scales enlarged, juxtaposed.

Forelimbs moderately long; upper arm shorter than lower arm (UAL $16.5 \%$ of SVL, LAL $19.4 \%$ of SVL). Hind limbs long, tibia longer than femur (FEL $18.1 \%$ of SVL, TBL $19.0 \%$ of SVL). Dorsal and ventral scales on both forelimbs and hind limbs smooth. Scales on manus and pes smooth. Digits elongated with slightly recurved claws. Subdigital lamellae entire, a few fragmented; lamellae on the basal phalanges, enlarged, subquadrangular. Interdigital webbing absent. Subdigital lamellae on finger I: 8 ( 1 enlarged basal scansor); finger II: 12 (5 enlarged basal scansors); finger III: 14 (5 enlarged basal scansors); finger IV: 13 (4 enlarged basal scansors); finger $\mathrm{V}$ : 12 (4 enlarged basal scansors); toe I: 8 (1 enlarged basal scansors); toe II: 12 (4 enlarged basal scansors); toe III: 15 (5 enlarged basal scansors); toe IV: 15 (6 enlarged basal scansors); toe $\mathrm{V}$ : 14 (4 enlarged basal scansors). Relative length of digits, fingers: $4>3>5>2>1$; toes: $4>3>5>2>1$.

Tail (original) subcylindrical, flattened below; its length greater than SVL (TL $106.7 \%$ of SVL). Tail base swollen. Dorsal scales of tail homogenous, granular, few small spine like tubercles on the sides, towards the base of the tail. Ventral scales imbricate; median subcaudals enlarged, hexagonal. A post cloacal spur present on either sides of the base of the tail.

Colouration in preservative: Head grayish brown; dorsum, grayish brown with a vertebral series of dark edged, paired pale brown spots; a distinct black, subrectangular spot on the nape; ventrals, white; tail pale brown above, with a series of indistinct dark and light markings; white below.

Colouration in life: Dorsum, pale brown with dark brown and dull white mottlings; a vertebral series of paired paler spots edged on the sides by darker brown spots; spine like tubercles on flanks, white; ventral side of body, white. Dorsum of head, mottled with buff yellow and dark brown; ventral side of head, in breeding males, bright yellow bordered by a dark line up to the throat; nape with a subrectangular black spot; ventral side of neck and abdomen white. Limbs pale brown, mottled with dark brown markings; fingers and toes cross barred with light and dark brown; tail pale brown, with a series of lighter, dark edged, spots; ventral side, white.

Variations: Most specimens had 9 supralabials except ZSI/WGRC/IR/V/2378A and 2380 which showed 10 supralabbials. Infralabials ranged from 8-9 except in ZSI/WGRC/IR/V /2381A,B which both showed 8 infralabials on the right and 7 infralabials on the left. Femoral pores were present only in males and ranged from $15-18$ on each femur. ZSI/WGRC/IR/V $/ 2380$ showed 16 femoral pores on the right and 15 femoral pores on the left.

Distribution: Recent field work throughout Kerala state has revealed the occurrence of Cnemaspis littoralis from the dry and coastal regions of Kozhikode district, previously a part of the Malabar region (type locality); Kannur district; Nellikuth and Nilambur, Malapuram district; Mannuthy, Thrissur district; Chitoor Government college, Palakad district (Palghat Gap); Kodanad and Cochin of Ernakulam district. Inger et al. (1984) reported the occurrence of $C$. littoralis from Ponmudi, Trivandrum district of Kerala. The occurrence of $C$. littoralis from Nilambur and Nellikuth ( $\sim 80 \mathrm{~km}$ from the coast) and from Chittur College, Palakad $(\sim 130 \mathrm{~km}$ from the Coast) suggests that this species is not restricted to the littoral of Kerala but also the dry and humid regions throughout Kerala.

Natural history: All the specimens observed were from trees close to human settlements or from teak, rubber, acacia and coconut plantations (Fig. 3). Individuals were also found as commensals to humans, living on trees around houses in the heart of Kannur, Calicut, Thrissur and Cochin, which are well developed cities. The neotype, ZSI/WGRC/IR/V/2377 was collected from a jackfruit tree in Chaliyam coast, Kozhikode district; other specimens (ZSI/WGRC/IR/V/2378A,B) were collected from a coconut tree in Narayamkulam, Kozhikode district; the male and female specimens collected from Kaprikad (ZSI/WGRC/IR/V/2379A,B) were found on acacia trees in an acacia plantation; the two males collected from Nellikuth (ZSI/WGRC/IR/V/2381A,B) were found on a teak tree. 


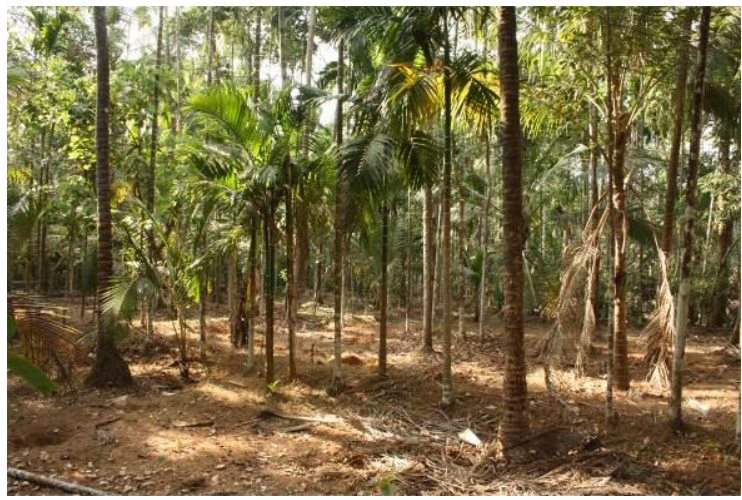

Figure 3: Habitat of $C$. littoralis neotype

Adult Cnemaspis littoralis exhibit a distinct sexual dimorphism, with males having a bright yellow throat which is absent in females. In Chaliyam, the second author observed the courtship behavior in two individuals (not collected), wherein the male approaches a female with slight jerks and slightly lifts its chin, exposing the bright yellow throat. Eggs were observed in Narayamkulum on coconut trees at a height of $10-12 \mathrm{~m}$. Most eggs were laid in pairs under the periyanth of the nuts, in the furrows created by the feeding of the Eriophid mite, Aceria guerreronis (Keifer) which is a major pest of coconuts in Kerala. The eggs are completely sheltered by the periyanth of the nuts (Fig. 4). This strategy of selecting coconuts affected by the eriophid mites might have developed as an antipredatory mechanism. However A. guerreronis is believed to have arrived to India and existed since the early 1960's (Haq, 2011) suggesting that $C$. littoralis have only recently learned to utilize affected coconuts as an oviposition site. Aceria guerreronis is also associated with two larger predatory mites Neoseiulus paspalivorus and $N$. baraki of the family Phytoseiidae (Domingos et al. 2010; Lawson-Balagbo et al. 2007; Moraes et al., 2004). These predatory mite colonies may also provide a stock of available food source for newly hatched $C$. littoralis. On one occasion, a cluster of 7 eggs was observed under the periyanth of a coconut, showing that $C$. littoralis may sometimes exhibit communal oviposition. Eggs were found during all the seasons, suggesting that this species may not have a particular breeding season or that they may have an extended breeding season. Two eggs, collected from under the periyanth of a coconut measured 6.6 x $5.1 \mathrm{~mm}$ and $6.4 \times 4.9 \mathrm{~mm}$. One of the eggs hatched after 12 days and the neonate measured $11.2 \mathrm{~mm}$ from snout to vent and had a tail length of $8.4 \mathrm{~mm}$. Dermatophagy was observed in the newly hatched $C$. littoralis (Fig. 5). The neonatal lizards also fed on the white footed ant (Technomyrmex sp.). Adult lizards were observed feeding on the eggs of the Longlegged ant Anoplolepis gracilipes (Fr. Smith) which is a major invasive species throughout the world causing alterations in the native ecosystem (Drescher et al., 2007). Adult lizards first inspected nest budding ant colonies moving on the ground from the base of trees at a height of around $30 \mathrm{~cm}$ from the ground. They then sally down and snatch a single egg from one of the ants and return back to the same tree. One individual $C$. littoralis was observed feeding on 5 ant eggs consecutively using the same technique.

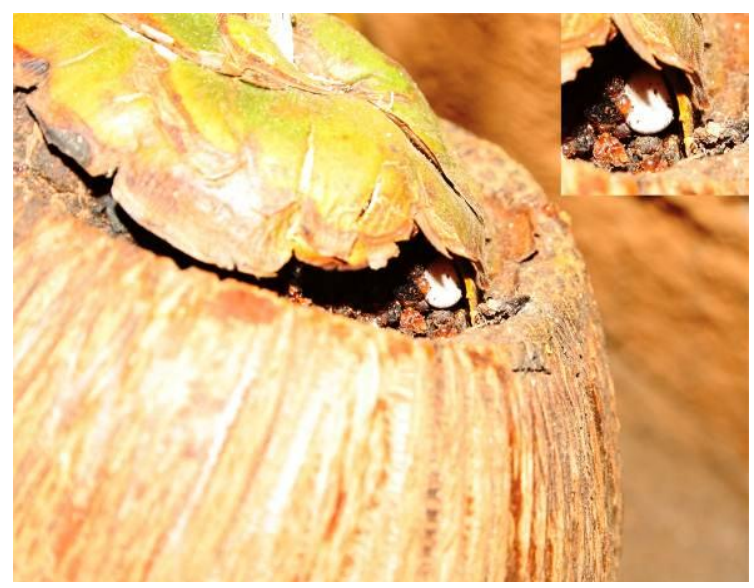

Figure 4: Eggs of $C$. littoralis under the periyanth of the coconut.

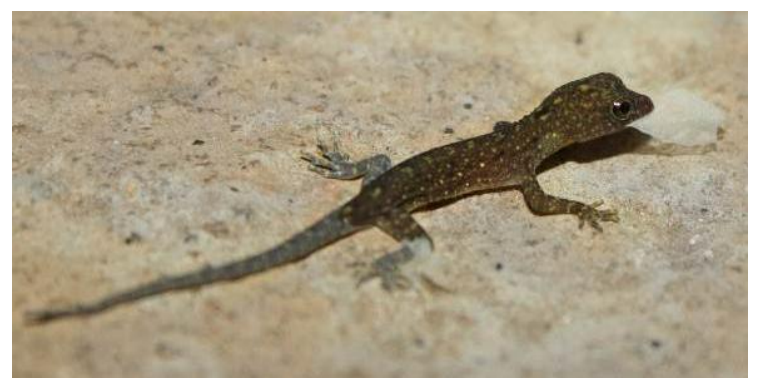

Figure 5: A newly hatched C. littoralis.

\section{Discussion}

The present designation of a neotype for Cnemaspis littoralis is according to Article 75.3 of the International Code of Zoological Nomenclature, ICZN (1999) and is based on specimens collected from the coastal areas of Kozhikode, Malapuram and Thrissur districts of Kerala (all previously a part of the Malabar region which stretched mainly from Kannur to Thrissur district of Kerala state), and match the 
original description of Jerdon (1853) in general morphology and colour. C. littoralis differs from all of its Indian congeners by the following characters. $C$. beddomei, $C$. nairi, $C$. ornata, C. otai, C. sisparensis, C. wynadensis, $C$. indica, and $C$. yercaudensis: absence of spine like tubercles on the flanks (vs. small, scattered spine like tubercles present on flanks in $C$. littoralis); $C$. indraneildasii, $C$. heteropholis and $C$. goaensis: dorsal scales heterogenous (vs. homogenous in C. littoralis); C. jerdonii: 8 femoral pores in males (vs. 15-18 femoral pores in C. littoralis); $C$. gracilis: Median series of subcaudals not enlarged ( $v s$. enlarged, hexagonal, in $C$. littoralis); $C$. mysoriensis: 2-3 femoral pores in males ( $v s$. 15-18 femoral pores in $C$. littoralis); $C$. australis: ventrals keeled (vs. ventrals smooth in C. littoralis); C. monticola, C. nilagirica, $C$. goaensis, $C$. wicksii and $C$. andersonii: ventral scales of neck carinate (vs. ventral scales of neck smooth in $C$. littoralis).

Beddome in 1871 described Gymnodactylus planipes from specimens collected from Nellicootah below the Nilgiris. Later, Günther (1875) considered $G$. planipes (erroneously spelt as G. planiceps in his account) to be a synonym of $G$. littoralis, but did not provide the reasons to do so. Boulenger (1885) however, supported Günther's view and synonymized $G$. planipes with $G$. littoralis based on examining Beddome's type collected from Nellicootah and Nilambar deposited at the British Museum of Natural History (BMNH). Manamendra-Arachchi et al., (2007) presumed the type locality of $C$. planipes to be Nellakota situated at an altitude of $1500 \mathrm{~m}$ and $\sim 80 \mathrm{~km}$ from the west coast of Kerala and considered it unlikely that $C$. planipes is a synonym of $C$. littoralis as the type locality of $C$. planipesNellakota is not of the littoral side of Malabar. The fact that virtually no other Cnemaspis have a range from sea level to well over $1500 \mathrm{~m}$ needs to be addressed (pers. com. Aaron Bauer, May 2013). Our examinations of specimens from Nellikuth (12 km from Nilambur) of Malapuram district, which we assume to be the type locality of $C$. planipes, match our present description of $C$. littoralis. Beddome's description of Gymnodactylus planipes, " Of slender form, snout elongate, body and tail uniformly granular without tubercles, pupils round, subcaudals enlarged, 8 upper labials, the 2 last being very minute, 6 lower labials, median shield very large, angular behind and separating the chin shields of which there are 2 small scale-like pairs, femoral pores 16-17 on each thigh, none in the preanal region, the plates on the lower portion of the fingers and toes large and flat, the terminal one much dilated and 3 times as large as the others; maximum length $23 / 4$ inches, of a greyish color, with a prominent black blotch on the nape of the neck and generally a row of white black edged spots down the back" is strongly consistent with the present description of $C$. littoralis collected from the same topotype. Moreover, we have observed individuals of $C$. littoralis from Chittur Government College, Palakad which is $\sim 130 \mathrm{~km}$ from the Coast and not of the littoral side of Kerala. Hence, based on our collections from Nellikuth, Nilambur and the coastal belt of Kozhikode and Thrissur, we consider $C$. planipes to be a synonym of $C$. littoralis according to Article 23.3 of the ICZN.

Cnemaspis littoralis is the most widely distributed species of Cnemaspis among the Indian congeners. The ability of this species to learn new behaviors such as ovipositing in coconuts affected by eriophid mite, which has only recently colonized India, may have also contributed to the dispersal of this species. Despite its wide distribution, the lack of taxonomic clarity for $C$. littoralis, indicates that the genus Cnemaspis has for too long been ignored. Hence further studies are needed to resolve several taxonomic confusions within this genus.

\section{Acknowledgements}

We give our heartfelt thanks to Anil Zachariah for his continuous support and encouragement throughout the work. We also thank Muhammad Jafer Palott (ZSI) for helping in registration of specimens. We also thank $\mathrm{C}$. Bejoy for providing stay and supporting us during our field visits and also for helping in identification of the ant species; to Ashwant R.A. for permitting us to study the lizards in his property; to Dhanya Balan, Babu Balan and Shiva Kumar for helping us to edit the photos; to Sandeep Das, Roshnath R. and George Chandy (Course Director, M.S program in Wildlife Studies) for their encouragement. Finally we would like to thank Aaron Bauer (Villanova University, USA) for reviewing the manuscript. 


\section{Literature cited}

Annandale, N., 1915. Herpetological notes and descriptions. Records of the Indian Museum, 11: 341-347.

Bauer, A. M., 2002. Two new species of Cnemaspis (Reptilia: Squamata: Gekkonidae) from Gund, Uttara Kannada, India. Mitteilungen aus dem Naturhistorischen Museum in Hamburg, 99: 155-167.

Beddome, R. H., 1870a. Descriptions of some new lizards from the Madras Presidency. Madras Journal of Medicine \& Science, 1: 30-35.

Beddome, R. H., 1870b. Descriptions of new reptiles from the Madras Presidency. Madras Journal of Medicine \& Science, 2: 169-176.

Beddome, R. H., 1871. Descriptions of new reptiles from the Madras Presidency. Madras Journal of Medicine \& Science, 4: 401-404.

Boulenger, G. A., 1885. Catalogue of the lizards in the British Museum (Natural History). Vol. 1. Taylor and Francis, London: 450.

Das, I. and A. M. Bauer, 2000. Two New Species of Cnemaspis from Tamil Nadu, southern India. Russian Journal of Herpetology, 7 (1): 17-28.

Domingos, C. A., J. W. Da S. Melo, M.G.C. Jr. Gondim, G. J. De Moraes, R. Hanna, L. M. Lawson-Balagbo and P. Schausberger, 2010. Diet-dependent life history, feeding preference and thermal requirements of the predatory mite Neoseiulus baraki (Acari: Phytoseiidae). Experimental \& Applied Acarology, 50: 201-215.

Drescher, J., N. Blüthgen and H. Feldhaar, 2007. Population structure and intraspecific aggression in the invasive ant species Anoplolepis gracilipes in Malaysian Borneo. Molecular Ecology, 16 (7): 1453-1465.

Giri, V. B., I. Agarwal and A. M. Bauer, 2009. Designation of a Neotype for Cnemaspis mysoriensis (Jerdon, 1853) (Sauria: Gekkonidae), with redescription and notes on its distribution and habitat. Russian Journal of Herpetology, 16 (4): 256-264.

Günther, A., 1864. The Reptiles of British India, The Ray Society, London: 444.

Gray, J. E., 1846. Descriptions of some new species of Indian lizards. Annals and Magazine of Natural History, 18: 429-430.
Günther, A., 1875. Second report on collections of Indian reptiles obtained by the British Museum. Proceedings of the Zoological society of London, 1875: 224-234.

Haq, M. A., 2011. Coconut density after the invasion of Aceria guerreronis (Acari: Eriophyidae) in India. Zoosymposia, 6: 160-169.

Inger, R. F., H. Marx and M. Koshy, 1984a. An undescribed species of gekkonid lizard (Cnemaspis) from India with comments on the status of C. tropidogaster. Herpetologica, 40 (2): 149-154.

Inger, R. F., H. B. Shaffer, M. Koshy and R. Bakde, 1984b. A report on a collection of amphibians and reptiles from the Ponmudi, Kerala, South India. Journal of the Bombay Natural History Society, 81 (2): 406-570.

Jerdon, T. C., 1854 (1853). Catalogue of reptiles inhabiting the Peninsula of India. Journal of the Asiatic Society of Bengal, 22: 462-479.

Lawson-Balagbo, L. M., M. G. C. Jr. Gondim, G. J. de Moraes, R. Hanna and P. Schausberger, 2007. Refuge use by the coconut mite Aceria guerreronis: fine scale distribution and association with other mites under the perianth. Biological Control, 43: 102-110

Manamendra-Arachchi, K., S. Batuwita, and R. Pethiyagoda, 2007. A taxonomic revision of the Sri Lankan day-geckos (Gekkonidae: Cnemaspis), with description of new species from Sri Lanka and southern India. Zeylanica, 7 (1): 9122.

Moraes, G. J. de, P. C. Lopes and L. C. P. Fernando, 2004. Phytoseiid mites (Acari: Phytoseiidae) of coconut growing areas in Sri Lanka, with descriptions of three new species. Journal of Acarological Society, Japan, 77: 1-20.

Mukherjee, D., S. Bhupathy and A. M. A. Nixon, 2005. A new species of day gecko (Squamata, Gekkonidae, Cnemaspis) from the Anaikatti Hills, Western Ghats, Tamil Nadu, India. Current Science, 89 (8): 1326-1328.

Murthy, T. S. N., 1990. A field book of the lizards of India. Records of the Zoological Survey of India: 116 
Smith, M. A., 1935. The fauna of British India, including Ceylon and Burma; Reptilia and Amphibia. Vol. 2: Sauria. Taylor and Francis, London: xiv+440+1pl.

Srinivasan, M., G. Ramaswamy and P. S. Easa, 1998. Studies on Lizard Diversity in Selected Sacred Grooves of Kerala. Cobra, 34: 12-15.
Theobald, W., 1876. Descriptive catalogue of the reptiles of British India. Thacker, Spink and Co., Calcutta: xiii+238.

Tikader, B. K. and R. C. Sharma, 1992. Handbook of Indian Reptiles. Zoological Survey of India, Calcutta: 250.

Table 1: Measurements and Pholidosis of neotype and addition specimens of Cnemaspis littoralis, collected from different localities in Kerala (All measurements in $\mathrm{mm}$ ).

\begin{tabular}{|c|c|c|c|c|}
\hline \multirow[t]{2}{*}{ Parameters } & \multirow{2}{*}{$\begin{array}{c}\text { Neotype } \\
\text { ZSI/WGRC/IR/V/2377 }\end{array}$} & \multicolumn{3}{|c|}{$\begin{array}{c}\text { Other materials (including neotype) } \\
\text { (ZSI/WGRC/IR/V/2377-2382) }\end{array}$} \\
\hline & & Range & Mean & SD \\
\hline SVL & 31.5 & $27.9-31.6$ & 30.02 & 1.6069 \\
\hline $\mathrm{AG}$ & 14.3 & $10.4-14.3$ & 13.02 & 1.6774 \\
\hline TW & 6.1 & $4.4-6.2$ & 5.42 & 0.6431 \\
\hline ED & 1.7 & $1.5-1.8$ & 1.61 & 0.1246 \\
\hline EN & 3.1 & $2.5-3.1$ & 2.9 & 0.2138 \\
\hline ES & 3.9 & $2.6-4.1$ & 3.67 & 0.4995 \\
\hline ET & 2.7 & $2.1-2.9$ & 2.48 & 0.3182 \\
\hline IN & 1 & $0.5-1.0$ & 0.77 & 0.1488 \\
\hline TD & 0.5 & $0.3-0.5$ & 0.42 & 0.0707 \\
\hline $\mathrm{HL}$ & 9.1 & $7.2-9.3$ & 8.32 & 0.7166 \\
\hline HW & 5.3 & $4.1-5.3$ & 4.56 & 0.4173 \\
\hline HD & 3.5 & $2.7-3.6$ & 3.22 & 0.3059 \\
\hline IO & 2.9 & $2.5-3.4$ & 3.03 & 0.2774 \\
\hline UAL & 5.2 & $3.6-5.2$ & 4.18 & 0.4883 \\
\hline LAL & 6.1 & $4.3-6.1$ & 5.05 & 0.5372 \\
\hline PAL & 3.1 & $2.8-3.5$ & 3.16 & 0.2264 \\
\hline FL1 & 1.7 & $1.2-1.7$ & 1.43 & 0.1506 \\
\hline FL2 & 2.4 & $2.1-2.5$ & 2.3 & 0.1512 \\
\hline FL3 & 2.6 & $2.5-2.9$ & 2.68 & 0.1246 \\
\hline FL4 & 3.2 & $3.1-3.6$ & 3.21 & 0.1727 \\
\hline FL5 & 2.1 & $2.0-2.3$ & 2.22 & 0.1165 \\
\hline FEL & 5.7 & $4.9-5.7$ & 5.23 & 0.2615 \\
\hline TBL & 6 & $4.4-6.0$ & 5.41 & 0.4941 \\
\hline TOL1 & 1.5 & $1.3-1.8$ & 1.48 & 0.1458 \\
\hline TOL2 & 2.7 & $2.3-2.9$ & 2.62 & 0.1909 \\
\hline TOL3 & 3.2 & $2.7-3.4$ & 3.13 & 0.2446 \\
\hline TOL4 & 3.8 & $3.3-3.9$ & 3.61 & 0.2295 \\
\hline TOL5 & 2.8 & $2.5-3.0$ & 2.7 & 0.1852 \\
\hline TL & 33.6 & $28.7-35.2$ & 32.06 & 2.5185 \\
\hline TBW & 3.5 & $2.8-3.7$ & 3.27 & 0.3314 \\
\hline Supralabials (R/L) & $(9 / 9)$ & $9-10$ & & \\
\hline Infralabials (R/L) & $(8 / 8)$ & $7-9$ & & \\
\hline Femoral pores & $17 / 17$ & $15-18$ & & \\
\hline Lam IV manus & 13 & $13-14$ & & \\
\hline Lam IV pes & 15 & $15-16$ & & \\
\hline
\end{tabular}

\section{Comparative materials:}

Cnemaspis littoralis: ZSI/WGRC/IR/V/2378, two adult males, Narayamkulam, Kozhikode District, Kerala (11.50749 N, 75.80667 E), Umesh P. K., 14 December 2011; ZSI/WGRC/IR/V/2379, adult male \& adult female, Kaprikad, Ernakulam District, Kerala (10.18308 N, 76.51633 E), Vivek Philip Cyriac, 26 October 2011; ZSI/WGRC/IR/V/2380, adult male, Chaliyam, Kozhikode District (11.16095 N, 75.80838 E), Umesh P. K., 6 February 2012; ZSI/WGRC/IR/V/2381, two adult males, Nellikuth, Malapuram District (11.35676 N, 76.3083 E), Umesh P. K., 19 February 2012. 


\section{PLATE 5}
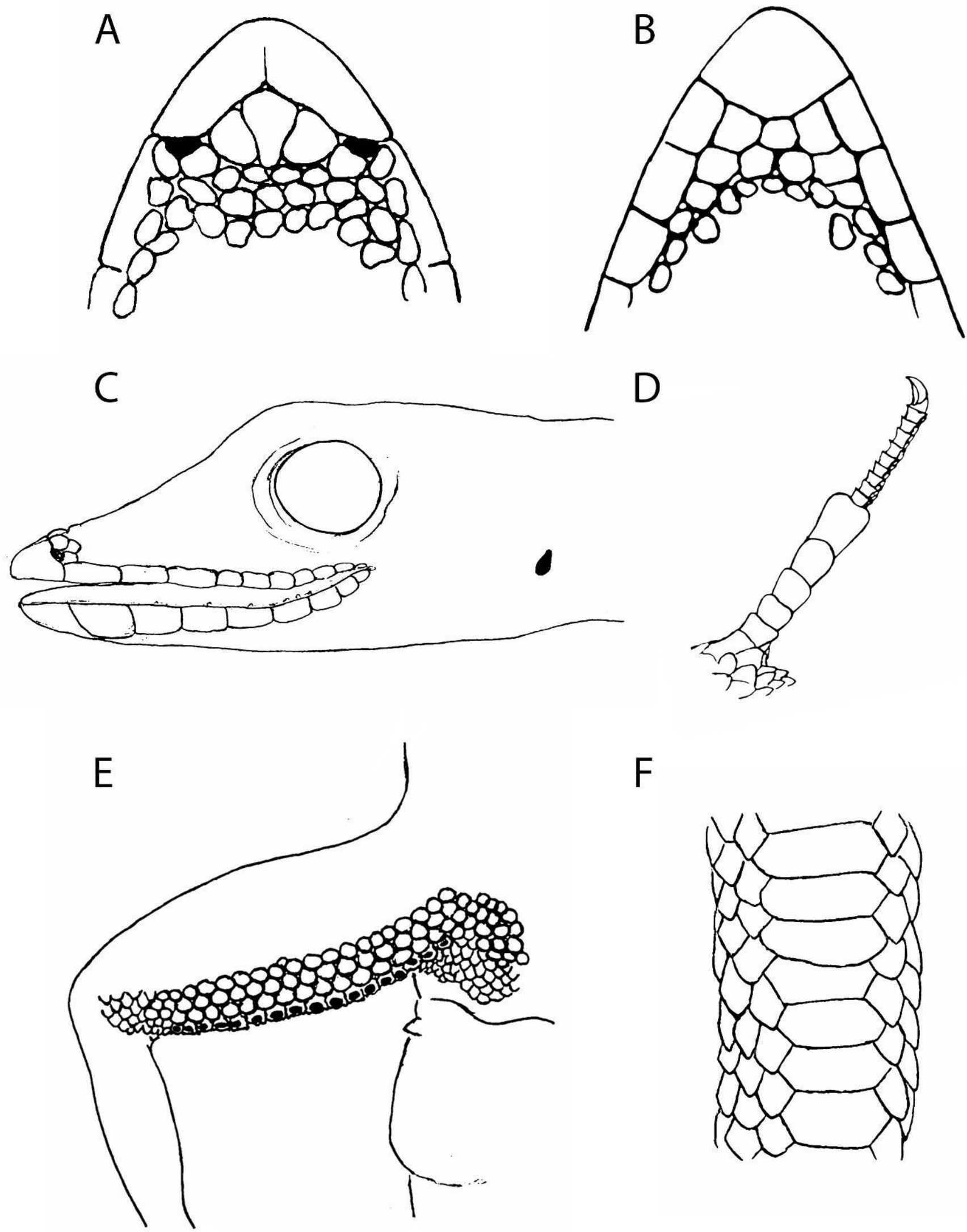

$\mathrm{F}$

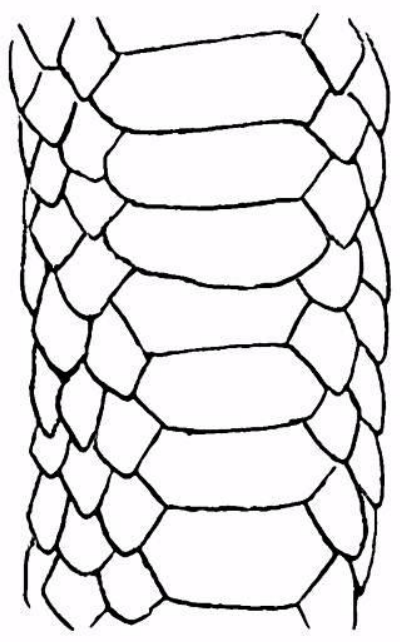

Figure 2: Cnemaspis littoralis, Neotype, ZSI/WGRC/IR/V/2377, A, dorsal scales on snout; $\mathbf{B}$, ventral scales of chin; C, lateral view of head showing labials; D, fourth toe of right pes showing subdigital lamellae; E, Left hind limb and preanal region showing femoral pores and enlarged juxtaposed scales on thighs and preanal region; F, A portion of hexagonal subcaudal scales. 